\title{
Mycobacterium chimaera-induced tenosynovitis in a patient with rheumatoid arthritis
}

\author{
Ryu Watanabe, ${ }^{1}$ Hiroto Seino, ${ }^{2}$ Shinji Taniuchi, ${ }^{3}$ Ryotaro Igusa ${ }^{4}$
}

'Department of Rheumatology, Osaki Citizen Hospital, Osaki, Japan

${ }^{2}$ Department of Plastic and Reconstructive Surgery, Osaki Citizen Hospital, Osaki, Japan ${ }^{3}$ Department of Pathology, Osaki Citizen Hospital, Osaki, Japan

${ }^{4}$ Department of Respiratory Medicine, Osaki Citizen Hospital, Osaki, Japan

\section{Correspondence to} Dr Ryu Watanabe; doctorwatanaberyu7@gmail. com

Accepted 5 January 2020

Check for updates

(C) BMJ Publishing Group Limited 2020. No commercial re-use. See rights and permissions. Published by BMJ.

To cite: Watanabe $R$,

Seino H, Taniuchi S, et al. BMJ Case Rep 2020;13:e233868. doi:10.1136/bcr-2019233868

\section{DESCRIPTION}

A 61-year-old man with a 4-year history of seronegative rheumatoid arthritis presented to our clinic with swelling of the right hand that deteriorated over 6 months (figure 1A). The treatment included methotrexate (12 mg/week), tacrolimus (1 mg/day) and prednisolone $(4 \mathrm{mg} /$ day). Physical examination revealed redness and soft tissue swelling in the right middle finger, right thumb and right wrist as well as serous fluid discharge (figure 1A, yellow arrows). Laboratory testing revealed elevated $\mathrm{C}$ reactive protein levels (CRP, $22.5 \mathrm{mg} / \mathrm{L}$ ). The Disease Activity Score 28-CRP was 4.39. Ultrasound imaging in the swollen joints revealed irregularly expanded synovium with power Doppler signal (figure 1B). Short tau inversion recovery imaging showed tenosynovitis in the right middle finger (figure $1 \mathrm{C}$, red arrows). An extensive incision was made for debridement. Histopathological study of the tissue demonstrated inflammatory cell infiltration and multinucleated giant cells suggestive of mycobacterial infection (figure 1D, white arrows). Two months later, Mycobacterium chimaera was

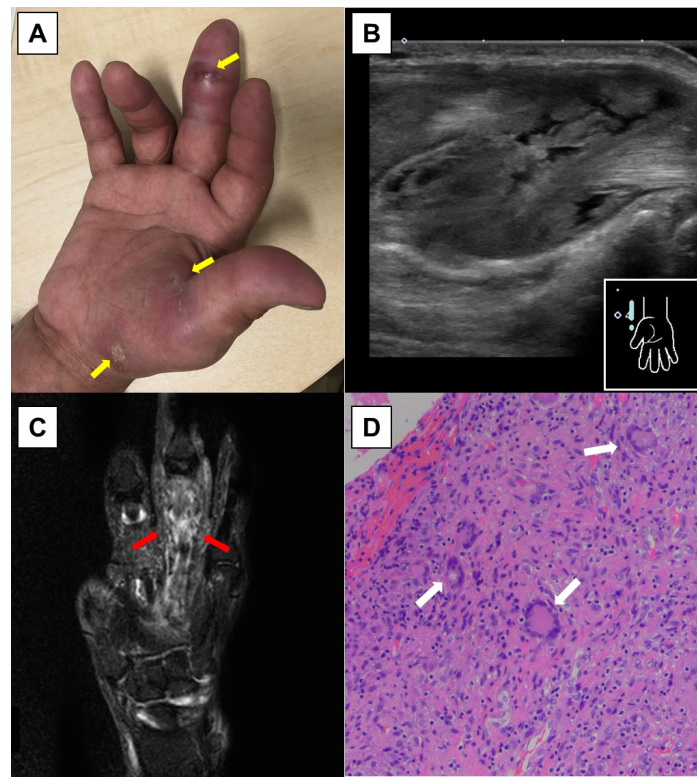

Figure 1 Mycobacterium chimaera-induced tenosynovitis in the right hand. (A) Gross appearance of the right hand. Serous fluid discharge was observed (yellow arrows). (B) Ultrasound image of the flexor tendon in the right wrist. (C) Short tau inversion recovery image of the right hand. Extensive tenosynovitis was observed in the middle finger (red arrows). (D) Histological study of the tissue revealed inflammatory cell infiltration and multinucleated giant cells (white arrows) in synovial tissue (H\&E stain; magnification $\times 200$ ).

\section{Learning points}

- Non-tuberculosis mycobacterium (NTM)induced tenosynovitis has been increasing in rheumatoid arthritis.

- Mycobacterium chimaera, a novel variant of NTM, accounts for one-third of Mycobacterium avium complex.

- Mycobacterium chimaera can cause tenosynovitis.

cultured from two tissue samples and identified in mass spectrometry. Antimycobacterial combination therapy with rifampicin, ethambutol and clarithromycin was initiated. Four months later, the patient is still on the therapy.

M. chimaera is a slow-growing non-tuberculosis mycobacterium (NTM) abundant in soil, dust and water. ${ }^{1}$ This species was newly isolated as a novel variant of NTM in 2012. ${ }^{2}$ Traditionally, mycobacterium avium complex (MAC) was thought to comprise M. avium and Mycobacterium intracellulare; however, recent genetic sequencing has revealed that $M$. chimaera is a major component of MAC, accounting for one-third of all MAC infections. ${ }^{3}$ After the introduction of biological diseasemodifying antirheumatic drugs, NTM-induced tenosynovitis has been increasingly reported in patients with rheumatoid arthritis. However, this case illustrates for the first time that $M$. chimaera can cause tenosynovitis.

Acknowledgements We thank Enago (https://www.enago.jp/) for the language editing.

Contributors RW, HS and RI provided medical care for the patient. ST provided pathological assessment. RW wrote the manuscript. All authors have reviewed and approved the manuscript.

Funding The authors have not declared a specific grant for this research from any funding agency in the public, commercial or not-for-profit sectors.

Competing interests None declared.

Patient consent for publication Obtained.

Provenance and peer review Not commissioned; externally peer reviewed.

\section{REFERENCES}

1 Schreiber PW, Sax H. Mycobacterium chimaera infections associated with heater-cooler units in cardiac surgery. Curr Opin Infect Dis 2017;30:388-94.

2 van Ingen J, Hoefsloot W, Buijtels PCAM, et al. Characterization of a novel variant of Mycobacterium chimaera. J Med Microbiol 2012;61:1234-9.

3 Boyle DP, Zembower TR, Reddy S, et al. Comparison of clinical features, virulence, and relapse among Mycobacterium avium complex species. Am J Respir Crit Care Med 2015;191:1310-7. 
Copyright 2020 BMJ Publishing Group. All rights reserved. For permission to reuse any of this content visit https://www.bmj.com/company/products-services/rights-and-licensing/permissions/

BMJ Case Report Fellows may re-use this article for personal use and teaching without any further permission.

Become a Fellow of BMJ Case Reports today and you can:

- Submit as many cases as you like

Enjoy fast sympathetic peer review and rapid publication of accepted articles

Access all the published articles

- Re-use any of the published material for personal use and teaching without further permission

Customer Service

If you have any further queries about your subscription, please contact our customer services team on +44 (0) 2071111105 or via email at support@bmj.com.

Visit casereports.bmj.com for more articles like this and to become a Fellow 